\title{
Sírios e libaneses no oeste paulista - décadas de 1880 a $1950^{*}$
}

\author{
Oswaldo Truzzi ${ }^{* \star}$
}

0 artigo busca explorar os condicionantes e características distintivas da inserção socioeconômica de sírios e libaneses no interior paulista, entre as décadas de 1880 e 1950. Do início difícil como mascates, portadores de uma cultura distante, os sírios e libaneses lograram se firmar como comerciantes, aproveitando as oportunidades que suas redes (de parentes e conterrâneos) e a economia cafeeira em expansão ofereciam, estabelecendo-se sobretudo nos ramos de roupas, tecidos e armarinhos de secos e molhados e de gado e cereais. Tomando como fonte principal uma série de obras - acadêmicas e memorialísticas -, nas quais o imigrante sírio e libanês é retratado no interior, o artigo indica ainda as principais regiões do oeste paulista nas quais o grupo se concentrou, discute trajetórias que ilustram algumas das possibilidades de mobilidade, a formação de lideranças, o modo como as práticas religiosas se transformaram e a mobilidade acentuada - como doutores e políticos - conquistada por estratos da primeira geração nascida no Brasil.

Palavras-chave: Sírios e libaneses. Oeste paulista. Mobilidade socioeconômica. Integração. Identidade. Lideranças étnicas.

\footnotetext{
*A pesquisa que originou este artigo foi financiada pela Fapesp e CNPq, respectivamente, no âmbito dos projetos "Percursos histórico-sociais na incorporação de imigrantes no oeste paulista (1880-1950)" [proc. 2015/20577-6] e “Migrações internacionais na formação do tecido social do interior paulista" (1880-1950)" [proc. 308322/2018-5].

** Universidade Federal de São Carlos (UFSCar), São Carlos-SP, Brasil (truzzi@ufscar.br; https://orcid.org/000-0002-9046-5092).
} 


\section{Introdução}

0 objetivo deste artigo é explorar os condicionantes e características distintivas da inserção socioeconômica de sírios e libaneses, ${ }^{1}$ especificamente, no oeste paulista ${ }^{2}$ entre as décadas de 1880, quando iniciou-se a imigração em massa para São Paulo, e de 1950, período em que já se observava uma entrada vigorosa de filhos de sírios e libaneses nas profissões liberais.

A maior parte da bibliografia especializada sobre este grupo étnico privilegia estudá-lo na capital (seja paulista, seja de outros estados), derivando daí comentários e observações marginais sobre sua inserção no interior (FRANCISCO, 2017; JACOB, 2014; KHOURI, 2013; OLIVEIRA, 2010; PINTO, 2010; TRUZZI, 2008a; BRANDÃO, 2007; SOUZA, 2003; CABREIRA, 2001; GATTAZ, 2001; NUNES, 1996; RIBEIRO, 1997; CAMPOS, 1987; HAJJAR, 1985; SAFADY, 1972; KNOWLTON, 1961; JORGE, 1948; BASTANI, 1945; DUOUN, 1944; BACKEUSER, 1944; KURBAN, 1933), ou ainda é pautada por estudos cujo escopo é apenas local (SOUZA, 2007; YKEGAYA, 2006; GOMES, 2004; COELHO, 1998; BASTOS, 1988). Neste artigo, ao contrário, pretende-se um balanço mais abrangente - embora sem ser exaustivo - das trajetórias dos sírios e libaneses no interior paulista. Tal recorte se justifica na medida em que um volume bastante significativo de imigrantes desta origem teve por destino tal região do estado de São Paulo, bastando aqui se afirmar, por exemplo, que no censo realizado em 1920, dos 19.290 sírios e libaneses ${ }^{3}$ que habitavam o estado, 13.302 (portanto quase $70 \%)$ estavam no interior. ${ }^{4}$

\footnotetext{
${ }^{1}$ Até a Primeira Guerra Mundial, as regiões que hoje compreendem a Síria e o Líbano eram conhecidas como "Grande Síria” e pertenciam ao Império Otomano (HITTI, 1924). Com a derrota dos turcos, foi instalado em tais regiões o regime de protetorado francês, sendo que a independência política somente seria conquistada pelo Líbano em 1943 e pela Síria em 1945. 0 grosso da imigração em massa para São Paulo foi formada por cristãos e ocorreu entre 1895 e 1930, interrompido o fluxo durante os anos de guerra. Até esta se iniciar, os imigrantes chegavam ao Brasil com passaportes turcos, advinda daí a denominação mais popular do grupo. Após a guerra, no Brasil tais imigrantes passaram a ser identificados como sírios, até que a perspectiva de independência inflamou o nacionalismo libanês, exigindo identidades distintas que foram socialmente construídas para cada grupo (TRUZZI, 2008, cap. 3). No presente artigo, entretanto, sírios e libaneses são tratados em conjunto, dada a similaridade de suas trajetórias econômico-sociais. Em termos designativos, os censos brasileiros refletiram a inconstância das denominações: inicialmente foram agrupados com outros contingentes sob o rótulo de "outras nacionalidades", para em seguida serem classificados ora como turcos, turco-árabes, turco-asiáticos (até o desfecho da Primeira Guerra), e finalmente como sírios e libaneses. A vinda de muçulmanos ocorreu em números muito menores e foi bem menos frequente até pelo menos os anos 1950. Mais recentemente, tanto a Guerra Civil Libanesa (1975-1990) quanto a Guerra Civil na Síria (a partir de 2011) trouxeram contingentes de refugiados significativos, sobretudo de origem muçulmana (TRUZZI, 2008).

${ }^{2}$ Aqui conceituado como a porção do território paulista acima do Trópico de Capricórnio, o que exclui a capital e regiões litorâneas, bem como municípios do Vale do Paraíba pelos quais a cultura do café, tocada a braço escravo e originária de terras fluminenses, penetrou pioneiramente na primeira metade do século XIX. Observe-se ainda que a lavoura do café pouco se desenvolveu em latitudes abaixo deste trópico, dada a ocorrência mais frequente de geadas ou a qualidade inferior dos solos.

${ }^{3}$ No censo em questão, imigrantes sírios e libaneses foram referidos como "turco-asiáticos" e perfaziam apenas 2,3\% dos estrangeiros presentes no estado, constituindo portanto um grupo não muito numeroso, quantitativamente bem inferior aos italianos (48,1\%), espanhóis $(20,6 \%$ ) e portugueses $(20,1 \%$ e mais próximos, na época, dos japoneses (2,9\%). Entretanto, como veremos, sua inserção urbana, dedicação ao comércio e mobilidade socioeconômica dos imigrantes e da primeira geração nascida no Brasil incrementaram a visibilidade do grupo.

${ }^{4}$ Japoneses, espanhóis e italianos apresentavam, na época, taxas ainda maiores de fixação no interior paulista.
} 
Portanto, existe evidentemente uma lacuna, que pode ser expressa pela seguinte questão: que condicionantes e características distintivas presidiram a inserção socioeconômica de sírios e libaneses especificamente no oeste paulista, no período enfocado?

Metodologicamente, o presente artigo se vale de uma ampla revisão bibliográfica que abriga basicamente trabalhos acadêmicos (teses, dissertações, artigos e publicações em congressos), livros de caráter memorialístico, pesquisas em repertórios biográficos e necrológios, além de um levantamento anterior e outro mais recente sobre a inserção política de descendentes de sírios e libaneses realizado junto ao Tribunal Regional Eleitoral de São Paulo. Tais informações recolhidas foram selecionadas com base em critérios espaciais (o já definido "oeste paulista") e cronológicos (o período enfocado).

0 texto se organiza começando por pontuar o início difícil desses imigrantes como mascates, portadores de uma cultura distante, para em seguida indicar o relativo sucesso ao se estabelecerem como comerciantes, sobretudo, nos ramos de roupas, tecidos e armarinhos, de secos e molhados e de gado e cereais, aproveitando as oportunidades oferecidas por suas redes (de parentes e de conterrâneos) e pela economia cafeeira paulista em expansão. 0 artigo indica ainda as principais regiões do oeste paulista nas quais 0 grupo se concentrou e discute, mesmo que não exaustivamente, as trajetórias que ilustram algumas das possibilidades de mobilidade, a formação de lideranças, o modo como as práticas religiosas se transformaram e a mobilidade acentuada - como "doutores" e como políticos - conquistada por estratos da primeira geração nascida no Brasil.

\section{0 início como mascates}

Diferentemente de outros grupos que aderiram ao colonato, o padrão de assentamento dos árabes no interior paulista obedeceu aos condicionantes clássicos de mobilidade socioeconômica já analisados alhures (TRUZZI, 2008a) para o grupo como um todo: a partir da rua 25 de março, na capital paulista, sírios e libaneses foram se espraiando e ganhando freguesias crescentes - primeiramente na capital, em bairros mais distantes do centro, e em seguida fora dela, em municípios do interior do estado e mesmo de outros estados do Brasil.

Como não se trata de uma imigração subsidiada, o papel das redes migratórias (TRUZZI, 2008b; VILELA, 2011), formadas tanto por parentes quanto por conterrâneos, foi muito importante. "Mascatear era a atividade inicial dos recém-chegados, que, na maioria das vezes, se hospedavam na casa de 'patrícios' e amigos que já se dedicaram a esta atividade, o que estreitava ainda mais os laços entre eles” (ROSA, 2001b, p. 57).

E foi assim que o papai, com treze anos de idade, aportou no Brasil - em 1906. Veio para São Paulo, foi encaminhado para o interior do estado e foi dar na cidade de Barretos, onde por informação ele encontrou pessoas da mesma cidade natal ou da mesma região em que ele morava, no Líbano. (GATTAZ, 2012, p. 94)

Aos poucos, na terra de origem formou-se de certo modo uma cultura migratória (SANTOS et al., 2010), pelo menos em parte responsável por mobilizar contingentes 
expressivos em direção à "América”, onde quer que essa fosse compreendida (TRUZZI, 2008a, cap. 1). De fato, a acolhida por redes foi muito comum e bastante importante, pois, desse modo, o grosso dos imigrantes não chegava aqui sem nenhuma referência.

Eles haviam imigrado com base em decisões razoavelmente bem informadas sobre aonde ir e onde encontrar trabalho [...] Desde o início havia uma clara noção, fornecida pelos que chegaram antes, de por onde se deveria começar, do tipo de mobilidade a ser perseguida, de qual era o nicho em que a colônia havia se entrincheirado com sucesso, de onde, portanto, existia uma rede de conterrâneos funcionando efetivamente: provendo emprego, treinando e socializando o recém-chegado. (TRUZZI, 2008a, p. 68)

A trajetória típica inicial envolveu a mascateação, tanto em zonas urbanas quanto rurais, e o posterior estabelecimento de uma loja (nos termos da época, venda, armazém ou bazar) em pontos comerciais estratégicos: no meio rural, em encruzilhadas e entroncamentos viários; no meio urbano, junto a locais movimentados, como praças centrais, igrejas e estações ferroviárias. Nos quadros de uma economia cafeeira em permanente expansão, tanto econômica quanto geográfica (dada a marcha para o oeste, característica da expansão da fronteira de cultivo do café), não foi difícil ao grupo se acomodar em um nicho econômico específico, de comercialização de bens de consumo não duráveis, especialmente roupas, tecidos e armarinhos.

É comum que, na fase de mascateação, o indivíduo a cumpra como recém-chegado, normalmente solteiro, já que tal atividade, dada sua itinerância, pouco se presta a ser desenvolvida por um núcleo familiar. Entretanto, após alguns anos nessa atividade que the permite acumular certo capital e ao mesmo tempo identificar e cultivar alguma freguesia em uma determinada localidade, o vendedor ambulante decide se estabelecer com um negócio fixo. Para tanto, casa-se, pois necessitará do concurso familiar para tocar seu negócio.

Assim, de início concebida como provisória e idealizada, comportando, ao cabo de alguns anos, um retorno farto e bem-sucedido à terra de origem, a imigração sírio-libanesa foi aos poucos se enraizando irreversivelmente no destino, ainda que muitos retornassem buscando refazer a vida na origem ou simplesmente para buscar uma esposa que thes conviesse.

De fato, voltar depois de algum tempo, com recursos que, no contexto econômico da terra de origem, eram até que bastante expressivos, não foi difícil. Essa alternativa esteve presente para muitos que, realmente, o fizeram. Entretanto, difícil foi permanecer. A maioria dos que retornaram havia chegado ao Brasil na condição de solteiros, ganhou algum dinheiro e voltou; mas, ao comparar as possibilidades do Brasil com as da terra natal, optou por constituir família e migrar novamente. (TRUZZI, 2008a, p. 56)

Tanto na condição de mascate quanto na de proprietário de um negócio, o ponto que lhe serve de referência para abastecê-lo com mercadorias são os atacadistas da rua 25 de março, seus conterrâneos implantados há mais tempo:

Papai chegou e foi mascatear, ele comprava as coisas pra vender na roça, ele ia em São Paulo, fazia compra, comprava só botão, agulha, linha, meias, essas coisas mais simples. 
Aí ele foi juntando, foi trabalhando e montou uma lojinha, aí começou a vender bananas, bebidas, depois teve um armazém. (ROSA, 2001a, p. 57)

No meio rural, Deffontaines (1936, p. 27) observou que, desde os fins do século passado, "o campo de trabalho dos mascates se alargou consideravelmente, na mesma proporção em que o colono procurava se desembaraçar das compras nas lojas do fazendeiro e, por isso, os mascates representavam uma feliz concorrência ao armazém do patrão". Em função disso, tais vendedores embrenharam-se sertão adentro, percorrendo fazendas onde eram bem recebidos pelos colonos que preferiam com eles negociar. As condições de pagamento eram mais tolerantes e as compras fora da venda da fazenda diminuíam a dependência das famílias em relação aos fazendeiros.

Esperava-se pelo mascate contando os dias e horas de seu trajecto e quando por um motivo qualquer era levado a ausentar-se mais dias do que costumava, acontecia que os moradores preocupados com a sua demora mandavam a seu encontro pessoas para saber noticias suas (CHOEIRI, 1929).

Dessa forma, a população rural constituiu um importante mercado para o grupo. Esta circunstância também explica o estabelecimento de muitas famílias de sírios e libaneses em pequenas cidades dispersas ao longo de todo o interior paulista. Um observador atento menciona que, na minúscula Rio Preto de 1898 , onde não havia

[...] mais de 120 fogos para menos de 1000 habitantes, já o sírio estava dono do seu comércio. De 12 estabelecimentos existentes, 8 eram de propriedade deles. E havia, ainda, os mascates visitando todas as fazendas, indo a todos os recantos, farejando todas as casas, na oferta reiterada das quinquilharias e retalhos do seu baú. (ALMEIDA, 1943, p. 171)

Outros depoimentos confirmam a importância da clientela instalada nas fazendas e, de modo geral, no meio rural, para a mobilidade socioeconômica de sírios e libaneses no interior paulista: "[Papai] comprou uma loja num lugar chamado Figueira, onde era a fazenda dos Gomes dos Reis. A loja era na fazenda. Era loja de beira de estrada. Era o que tinha muito antigamente nas fazendas. Tinha em todas as fazendas" (GREIBER et al., 1998, p. 245).

Meu pai veio para o Brasil com 22 anos, em 1909. Ele ficou 9 anos na Argentina, para onde ele foi em 1900 [...] Papai veio para cá e, chegando aqui na capital, viu que a cidade era muito grande, que as posses dele não davam para viver. Ele foi então se embrenhando no interior. Naquele tempo não existia Catanduva, existia lá um riacho onde papai chegava e sentava, tomava lanche e depois andava. E foi indo, e foi indo e encontrou um vasto campo aberto, perto de um rio chamado Cubatão. Aí fez um boteco. Boteco é um barzinho onde tem arroz, feijão, batata - porque não era empório, lá não existia empório. Existia um balcão com bebidas e todas as coisas que se precisa, tem em todo o interior de São Paulo [...] Naquele tempo só tinha pinga [...] Ele começou a fazer a vida lá e foi indo, foi indo, foi indo e ficou um dos maiores cerealistas de Araraquara até São José do Rio Preto; a firma chamava Gattás \& Makul. Quando se falava do depósito de Gattás \& Makul, todo mundo respeitava. (GREIBER et al., 1998, p. 317-8) 


\section{Dificuldades iniciais: cultura e estranhamentos}

Para o imigrante recém-chegado, houve, evidentemente, muitas dificuldades iniciais relacionadas em geral à diferença entre os padrões culturais da terra de origem e aqueles vigentes no interior paulista: "Eles estranhavam tudo, a língua, a mesa - comida tão diferente -, os hábitos...” (GREIBER et al., 1998, p. 254).

[Papai] veio junto com dois imigrantes: um deles o Elias Cassab, cujo filho é desembargador. Eles chegaram em Gênova e esses dois senhores não sabiam vestir calça comprida, vestiam de trás para frente, eles só vestiam saia. Naquele tempo era só saia! Então eles chamaram papai e disseram para ele: 'Quando a gente vai no banheiro, a gente não precisa tirar a calça?' 'Não', disse papai: 'Vocês puseram de trás para frente'. (GREIBER et al., 1998, p. 318)

Especialmente o manejo do novo idioma constituía uma barreira a ser transposta o mais rapidamente possível, sobretudo para um grupo que necessitava se fazer entender para ter sucesso no comércio. Ademais, era preciso irradiar confiança para conquistar o cliente, o que exigia certa flexibilidade: "no comércio você [...] é obrigado a dizer amém para qualquer um. Meu marido sempre foi assim, sempre concordava [...] Era conhecido por causa disso, essa mansidão dele, uma pessoa mansa [...]". 5 "Eu tinha que ter amizade com o povo e criar simpatia”, recordou o libanês José Tanus Gastin em seu depoimento (GREIBER et al., 1998, p. 270). "Em Araçatuba, tinha muito patrício, a colônia árabe era bastante grande lá. Eu me dava muito bem com todo mundo [...] Eu tenho amigos tanto árabes quanto brasileiros, a gente precisa ter amizades” (GREIBER et al., 1998, p. 240-3).

Assim, parece não ser descabido pensar que muitos nomes aportuguesados buscavam também facilitar a aproximação de fregueses um tanto reticentes com a fônica árabe. Syria Drubi (1998, p. 77), ao biografar seu cunhado Neif, indica que

[...] a maioria dos libaneses, quando aportava nessas abençoadas terras tupiniquins, carregava uma maleta com miudezas em geral - roupas, rendas, frascos de cheiro saia a mascatear por esse Brasil afora. 0 nome, oriental e de pronúncia difícil, era logo substituído por outro, mais maneiro, mais feijão com arroz. E Neif tornou-se Camilo.

Havia, portanto, um esforço de aproximação ao cliente, que constitui a essência mesmo da atividade comercial. Tais práticas exigiram uma interação relativamente intensa com o outro no cotidiano, inclusive para desarmar preconceitos que o potencial cliente podia ter.

Eu aprendi o português depois de dois meses [...] Eu fazia sinais, a mesma coisa que um mudo, fazia um sinal, outro sinal. Quando eu chegava, me perguntavam: 'O senhor já almoçou?' Eu dizia que sim, mas era mentira, eu nem sabia o que era almoço. Chegava de noite: 'Já jantou?' 'Sim'. Nas casas de fazenda me davam leite com farinha de milho à noite, antes de dormir. Depois, quando eu soube o que era almoço, janta, dizia 'não' (GREIBER et al., 1998, p. 270).

\footnotetext{
${ }_{5}^{5}$ Entrevista com Rania Haddad realizada em sua residência em Jales, em 1 de março de 2017.
} 
Por outro lado, o tom comumente jocoso com que tais dificuldades são relatadas normalmente indica que elas não se cristalizaram e foram rapidamente superadas por seus protagonistas. Para tanto, contribuíram, de um lado, a rede de recebimento por parentes e conterrâneos, que logo trataram de acolher e "treinar" os recém-chegados no ofício de mascate, e, de outro, as oportunidades e carências em matéria de intermediação comercial que vigiam em todo o interior paulista, especialmente nas áreas rurais.

\section{Principais concentrações}

0 passo seguinte à fase de mascateação parece ter sido o estabelecimento de uma "venda", próxima a grandes fazendas, ou em um local de passagem, de movimento, estrategicamente situado para continuar atendendo à freguesia anteriormente conquistada no comércio ambulante. Mais algum tempo decorrido e mais algum pecúlio acumulado, a próxima etapa era "passar o ponto" a um patrício mais novo e fundar ou adquirir um armazém ou loja já na cidade. Em ambos os casos, era comum que fosse adotado o sistema de anotações de dívidas em cadernetas, facilitando o crédito para a freguesia.

Desse modo, esses imigrantes "passaram a conviver em pequenas vilas e povoados, formando uma lojinha, ao lado da igreja, ao lado da escola, ao lado da farmácia, e começando a viver aquela forma incipiente dos futuros municípios” (TRUZZI, 2008a). Rosa (2001b, p. 60) relata, por exemplo, que as primeiras casas comerciais sírio-libanesas de Altinópolis se concentravam principalmente no Largo da Matriz, em terrenos foreiros da Fábrica da Igreja, adquiridos por imigrantes.

A centralidade do meio urbano ampliava a clientela, ao mesmo tempo que a freguesia anterior era mantida, porque os colonos também frequentavam as vilas no final de semana, tanto para comercializarem o excedente de seus produtos de subsistência, quanto para adquirirem mercadorias, transações que não raramente ocorriam no estabelecimento do antigo mascate que thes atendia anteriormente, agora convertido em comerciante estabelecido.

Em 1924, Nassim Bachur veio ao Brasil juntar-se a seus cunhados na pequena Rifaina, às margens do rio Grande, na fronteira com Minas Gerais.

Com o dinheiro trazido da Síria, montou seu próprio armazém. Até hoje, Rifaina é uma pequena cidade, razão pela qual causa surpresa a possibilidade de que muitos estabelecimentos comerciais pudessem prosperar ali. Nassim nos explicou que todos os fazendeiros, sitiantes e os trabalhadores rurais das redondezas abasteciam-se na cidade, transformada em polo distribuidor dos gêneros não produzidos nas fazendas. (COELHO, 1998, p. 82)

Na região de Franca, Coelho apurou ainda que o sírio dava preferência a lugares menores (“arrumavam uma casinha, plantavam uma videira e uma horta"), enquanto "os libaneses preferiam as cidades maiores porque estavam acostumados com a vida urbana, diferentemente dos sírios que provinham mais da zona rural” (COELHO, 1998, p. 91). 
FIGURA 1

Interior da loja Paulista, em Amparo. Fundada em 1912 por João Miguel Matta e irmãos, a loja representa o produto de anos de mascateação pelo interior de São Paulo

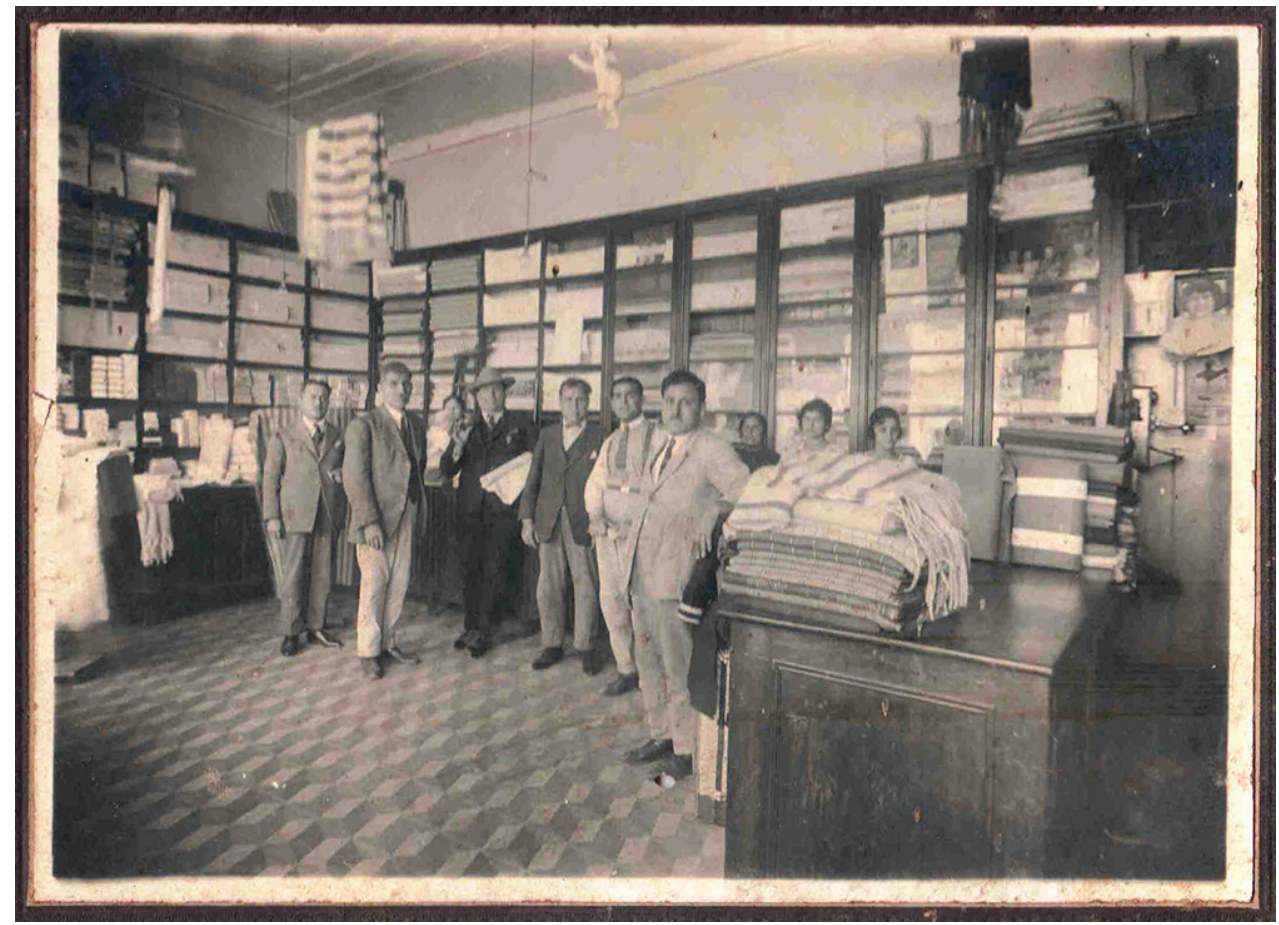

No extremo oeste do estado, à medida que novos núcleos urbanos foram progressivamente se adensando, o comerciante sírio ou libanês vislumbrou oportunidades ímpares de se estabelecer, realizando a intermediação entre as populações majoritariamente rurais e as mercadorias da capital. Este processo ocorreu ao longo de décadas. Uma das entrevistadas, referindo-se já aos anos 1960, recordou que

[...] em Jales, não tinha nada, desbravamos 6 o comércio, tudo estava por fazer. No primeiro dia que abriu a loja, vendeu quase $70 \%$ do estoque. Jales era centro de região, vinha gente de Minas, Mato Grosso, Goiás, um enorme movimento no comércio. Era tanto movimento que tive que colocar grades para organizar a entrada e saída da loja, uma leva entra, outra sai. (Entrevista com Rania Haddad e Aziz Haddad, realizada na casa dos entrevistados, em Jales, em 1 de março de 2017)

No oeste paulista, as maiores concentrações de sírios e libaneses em 1920 ocorriam em cinco regiões do estado, conforme se depreende do Mapa $1 .{ }^{7}$ A mais populosa delas se situava no extremo noroeste paulista e abrangia os até então vastos municípios de São José do Rio Preto (730 indivíduos), Barretos (553), Olímpia (243) e Penápolis (156), além

\footnotetext{
${ }^{6} 0$ uso do verbo desbravar é recorrente e significativo, pois o grupo se apresenta como uma espécie moderna de "bandeirante civilizador", que traz e difunde as novidades (mercadorias) da capital aos rincões mais distantes do estado.

${ }^{7}$ Os dados populacionais a seguir foram extraídos do Recenseamento Geral do Brasil de 1920 (BRASIL, 1922).
} 
dos vizinhos Monte Azul Paulista (156) e Catanduva (219), totalizando mais de 2.057 sírios e libaneses.

\section{MAPA 1}

Núcleos de concentração de sírios e libaneses, em municípios com mais de 200 habitantes Estado de São Paulo - 1920

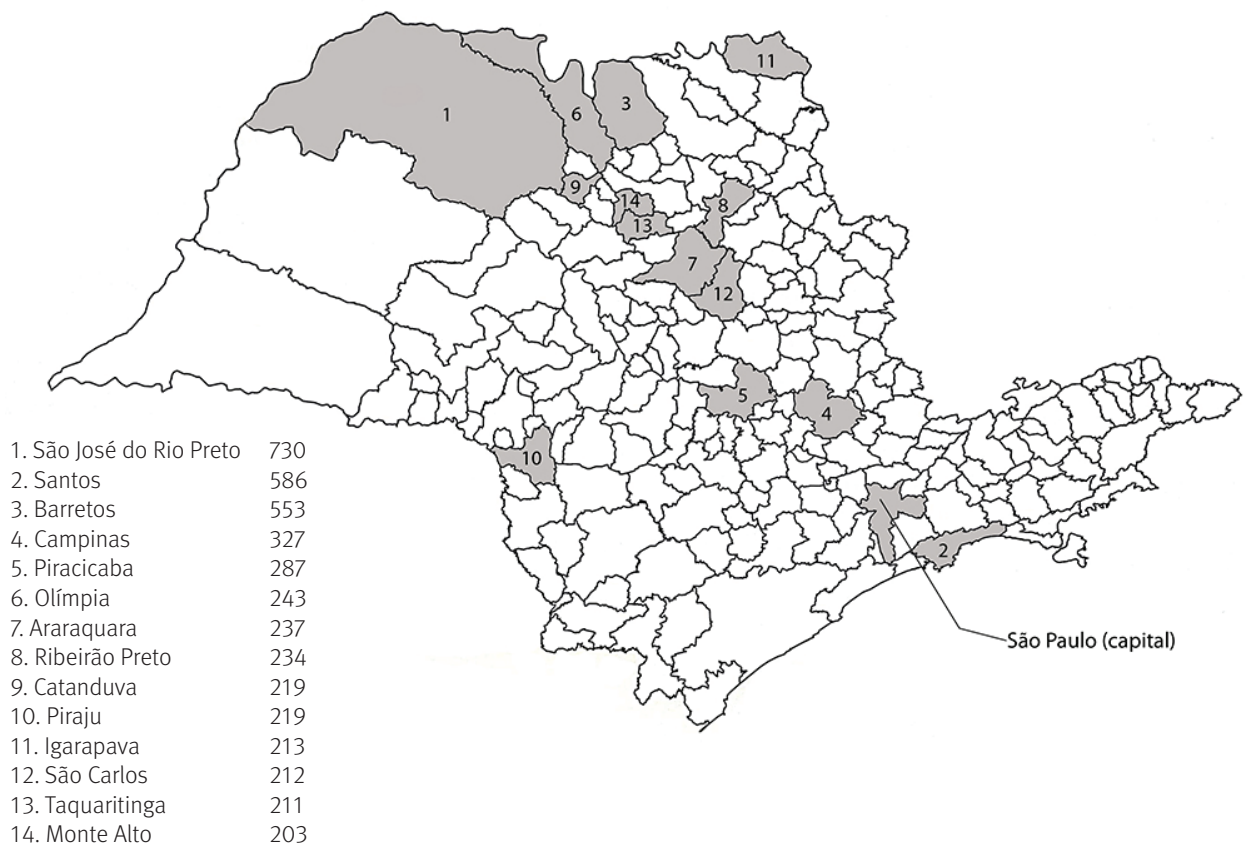

Fonte: Brasil (1922).

Uma segunda região, situada um pouco mais ao centro-norte do estado, envolveu as cidades de Araraquara (237), Ribeirão Preto (234), São Carlos (212), Taquaritinga (211), Monte Alto (203), Jaú (190), Jaboticabal (171), Pederneiras (167), Bariri (162) e Ibitinga (151), perfazendo 1.938 indivíduos, enquanto um terceiro núcleo abrangeu municípios de ocupação mais antiga no estado, no chamado "quadrilátero do açúcar”, no eixo formado pelos municípios de Campinas (327), Piracicaba (287) e Bragança Paulista (164), além da cidade de Sorocaba (182), acumulando 960 sírios e libaneses. Por fim, são também significativas a região do extremo nordeste do estado, polarizada por Igarapava (213), Franca (179) e Ituverava (153), computando 545 indivíduos, e a região do extremo centro-leste, polarizada pelos municípios de Piraju (219) e Santa Cruz do Rio Pardo (156), com 375 indivíduos.

No caso de Rio Preto, os primeiros imigrantes de origem sírio-libanesa chegaram à região por volta de 1890 , antes ainda da criação do município, ocorrida quatro anos mais tarde. ${ }^{8}$ Segundo apurou Arantes Neto (2001, p. 30), os primos Antoum Saab El Daher e Feres Saab, originários da cidade de Hadas El Jibe, ao norte do Líbano, foram os primeiros

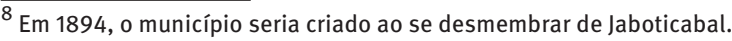


mascates que chegaram à região, abrindo caminho para uma torrente de conterrâneos e confirmando uma vez mais a importância das redes.

FIGURA 2

0 comerciante e ex-mascate libanês Daher (João) Audi, sua mulher Bekah (Amélia) Audi, filhos e netos em frente à sua loja Aurora, no município de Oriente, próximo a Marília, no interior de São Paulo

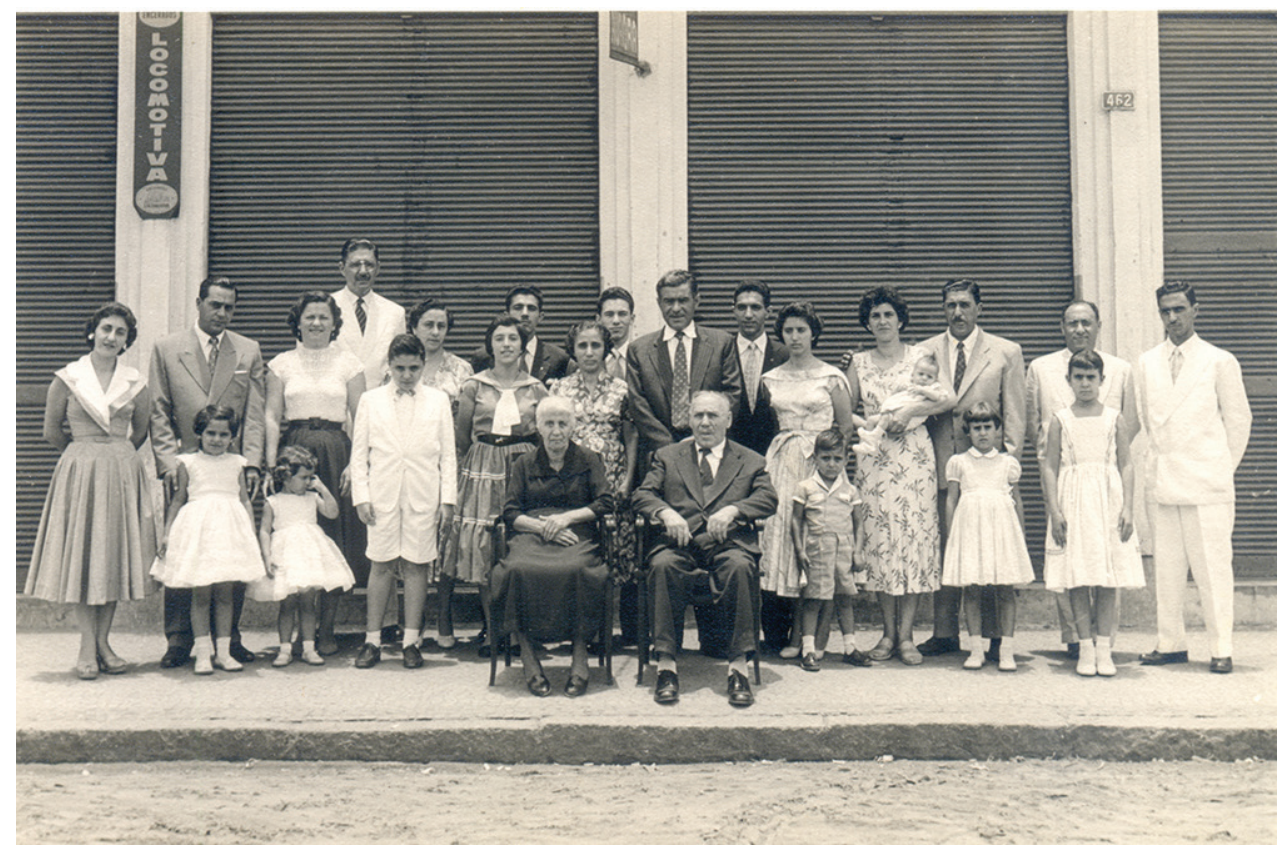

O Álbum da Comarca de Rio Preto, ${ }^{9}$ publicado em 1928, informou que

[...] após juntar um pouco de capital, os 'árabes' abriam uma loja e recebiam seus patrícios, que seguiam os mesmos passos no comércio até conseguir fortuna, mascatear era tão rentável a este povo que uma das primeiras ações da Câmara Municipal de Rio Preto foi aumentar as taxas para inibir o comércio ambulante. Em abril de 1896, o Legislativo determinou a cobrança de imposto no valor de um conto de réis por caixa. A taxa era exorbitante, já que o salário do prefeito era de um conto e duzentos mil réis. (FERNANDJES, 2008, p. 8)

Não obstante, a região atraía muitos mascates, a ponto de a receita de impostos por eles pagos representar $10 \%$ do orçamento municipal de $1898-99$, dobrando para $20 \%$ no exercício seguinte (BRANDI, 2012, p. 399). Aos poucos, segundo o que Fernandjes (2008) apurou, um número crescente de famílias foi se estabelecendo no município: Ajdar, Arif, Azem, Barcha, Bassitt, Buchala, Buzaidi, Calil, Chalela, Cury, Daud, Fahad, Fauaz, Gorayeb, Haddad, Hawilla, Homsi, Jamal, Kfoury, Madi, Mahfouz, Mitaini, Mussi, Muanis, Naffah,

\footnotetext{
${ }^{9} \mathrm{Na}$ época, a comarca abrangia uma vasta região, compreendendo os municípios de São José do Rio Preto (que incluía os distritos de Cedral, Engenheiro Schmidt, Ribeirão Claro, Ipiguá, Borboleta, Nova Aliança e Monte Bello), Mirassol (que incluía o distrito de Bálsamo), Monte Aprazível (que incluía o distrito de Neves), Tanabi, José Bonifácio, Potirendaba e Ignácio Uchôa.
} 
Rahad, Raduan, Scaff, Suriani, Tarraf, Taufic e Younes constam entre as pioneiras, que logo dominaram o comércio regional.

É claro que, no início, a presença marcante dos sírios e libaneses incomodou, em particular pela concorrência que faziam aos comerciantes estabelecidos de outras origens. A ponto de, em 1906, o aguerrido vereador de São José do Rio Preto e fundador de Monte Aprazível, Porfírio de Alcântara Pimentel, indignado com a língua inapreensível praticada entre sírios e libaneses em sua cidade, indicou a seus pares edis, num rasgo de "nacionalismo" sertanejo, a aprovação do seguinte projeto:

A bem popular e bem do governo municipal desta cidade: 1.)- Todos os negociantes árabes e turcos desta cidade não poderão continuar no comércio deste município sem ter um goarda livro esse que seja Brasileiro dentro de 30 dias [...]; 2.)- Todos os turcos que fallar na lingua turca perto de um brasileiro por cada vez que fallar multa de $10 \$ 000$ paga na boca do cofre municipal. Todo o brasileiro que ouvir elles fallando e não der parte ao fiscal multa de 10\$000. (ALMEIDA, 1943, p. 173)

Felizmente tal projeto de lei não foi aprovado.

O grande impulso ao desenvolvimento econômico deste município ocorreu com a chegada da Estrada de Ferro Araraquarense (EFA), em 1912 (ARANTES NETO, 2001, p. 149). A partir de então, São José do Rio Preto consolidou definitivamente sua vocação de polo regional, pois ao longo dos próximos 21 anos protagonizou o papel de "fim de linha", ao abrigar a última estação ferroviária do trajeto da EFA. Foi sobretudo por esta razão que lá se concentrou um número bastante expressivo de sírios e libaneses: as mercadorias eram embarcadas em São Paulo, trazidas até a "ponta dos trilhos", e de lá distribuídas por mascates e comerciantes naqueles sertões longínquos do oeste paulista, e também além fronteiras, já nos estados de Minas Gerais, Mato Grosso e Goiás.

A região dos atuais municípios de Barretos, Colina e Jaborandi também atraiu uma colônia significativa. Há indicações de que havia cicerones em São Paulo que drenavam imigrantes recém-chegados para esta região. Em Colina e Jaborandi, por exemplo, as famílias Drubi, Mustafa, Rajab, Taha, Rahal, Pedro, Cassim, Farra, Chabrour, Hamud, Zagluh e outras, que compuseram com o tempo uma grande descendência, procediam todas elas da mesma localidade, a minúscula aldeia de Kfarhamam, no sul do Líbano. Provavelmente já eram aparentados na origem e logo se estabeleceu uma corrente migratória relativamente volumosa que ligou o povoado à região de Barretos (DRUBI, 1998, 2007). É provável que houvesse outras redes semelhantes em outras cidades do interior. Coelho (1998, p. 96) observou que muitos dos sírios radicados em Franca vieram da localidade de Kreib, atualmente denominada Nássara. Elias Alasmar, em enfático depoimento a Greiber et al. (1998, p. 251), recordou que "em Jaú tinha muito patrício, mas a colônia de Hasbaïya era em Bariri. Lá havia sessenta famílias de Hasbaïya... tinha mais gente de Hasbaïya em Bariri do que na própria Hasbaïya (sic). Tem igreja ortodoxa até hoje em Bariri”. Por outro lado, Rosa (2001b, p. 46 e 54) destacou não apenas que a maioria dos descendentes da colônia em Altinópolis provinha da aldeia de Al Muzeible, atual Al Muzaini, mas também 
que se originaram de apenas dois varões: Ibrahim Asse e Ibrahim Abud, o que confirma a importância das redes operadas por laços de parentesco e conterraneidade, ${ }^{10}$ operando não somente no acolhimento do recém-chegado, mas também na operação do negócio, pela facilitação de créditos e mercadorias consignadas e transacionadas entre atacadistas, varejistas e mascates.

O comércio estabelecido quase sempre se concentrou no setor de secos e molhados, ou de tecidos e armarinhos, ou ainda de gado e cereais, ${ }^{11}$ este sempre acoplado a máquinas de beneficiamento (DRUBI, 1998, p. 72).

\section{Trajetórias e possibilidades de mobilidade}

Diferentemente da capital, onde o parque industrial tornou-se logo mais expressivo, é interessante notar que no interior o sucesso das atividades comerciais dos sírios e libaneses se desdobrou em investimentos nos setores imobiliário e agropecuário. Em Jales, a comerciante Rani Haddad, nascida no Líbano e que chegou ao Brasil somente em 1958, quando tinha 16 anos, não hesita em expor sua fórmula de sucesso, iniciada e alicerçada no comércio:

[...] começa com o comércio, abastece bem a loja, tem dinheiro para comprar a vista, porque consegue preço melhor, tem sua casa própria e seus dois carros em ordem e garante o estudo dos filhos. Daí o que sai de lucro, daí em diante vai aplicando em coisas diferentes: prédios, terrenos, imóveis, casas, fazendas, vai se aplicando na parte que dá mais lucro. Mas mantém o comércio sustentando. Até que aquela outra parte não começa a sustentar, não larga [o comércio]. ${ }^{12}$

Esta estratégia de mobilidade permitiu que muitos descendentes de sírios e libaneses no interior se tornassem proprietários de imóveis e depois fazendeiros. No primeiro caso, Choeiri já indicava em 1928, referindo-se a Rio Preto, que

[...] mais os preocupava terem suas casas próprias para melhor se installarem e progridirem nos seus negócios. Os seus lucros convertiam-se, assim que as marchas dos seus negócios o permitisse, em propriedades urbanas". E completa: "haverá uma prova mais frisante quanto a esta fé inabalável, de que esse formidável capital empregado em prédios que, até hoje, constituem a maior parte e quasi que os melhores da cidade[?]. (CHOEIRI, 1929)

Já no que concerne às propriedades rurais, ressalte-se serem bastante improváveis, entre imigrantes sírios ou libaneses, trajetórias exclusivamente rurais, pautadas pela progressiva ascensão de colonos a sitiantes e destes a fazendeiros. A esse respeito, é

\footnotetext{
${ }^{10}$ Tanto Nássara quanto Al Muzaini se situam no chamado Vale dos Cristãos, relativamente próximo à cidade de Homs.

${ }^{11} \mathrm{Na}$ Rio Preto de 1928, nada menos que metade dos compradores de cereais era de origem síria ou libanesa (CAVALHEIRO, 1929).

12 Entrevista com Rani Haddad, comerciante libanesa em Jales, em 14 de fevereiro de 2018. É interessante notar que a entrevistada aponta, porém, os limites da dedicação total ao comércio: "o comércio cansa, esgota, no comércio você não vive. No comércio a gente fica velha, quando vê, deu tudo pro comércio".
} 
significativa a trajetória do libanês Feres Sadalla, que chegou ao Brasil com sua esposa e um filho de colo em outubro de 1926. Acolhidos em Guariba por um tio de sua esposa, Feres, como era comum na colônia, começou a mascatear, inicialmente a cavalo, meses depois, com carroça, o que lhe permitia transportar mais mercadorias. Entretanto, conta uma de suas filhas já nascidas no Brasil, que "esse tipo de comércio não era seu forte. $\mathrm{Na}$ terra de origem, trabalhava na propriedade dos pais, onde cultivavam, sobretudo, oliveiras, industrializando azeite de oliva e criavam carneiros. Gostava mesmo era de trabalhar na terra" (GRISPINO, 2002, p. 12). Feres passou então a arrendar terras para plantar arroz, feijão, milho, amendoim, batata, cebola, alho, permanecendo um bom período no que sua filha denominou de

[...] luta rural. Nesse ínterim, surgiu a possibilidade de ampliar suas atividades, passando a comprar pomares de laranja e a vender a fruta colhida para compradores na cidade de São Paulo [...] Por um certo tempo, acumulou os afazeres agrícolas com o comércio de frutas. Foi, aos poucos, percebendo que a comercialização de frutas era bem mais rendosa e passou a dedicar-se, exclusivamente, a ela. Também não demorou a perceber que ele mesmo poderia vender a fruta em São Paulo, sem a intermediação de terceiros. (GRISPINO, 2002, p. 12)

Assim, Feres enviou para a capital dois de seus filhos. Depois deixou de embarcar as frutas em vagões e adquiriu caminhões para realizar o transporte. "Os horizontes começavam a se ampliar e Feres não parou de crescer. Comprou uma primeira propriedade rural, entre o município de Córrego Rico e Jaboticabal, toda plantada de laranjas pera e bahia. Outras foram sendo adquiridas, uma de maior porte que a outra" (GRISPINO, 2002, p. 13). Ao falecer em 1957, há apenas duas décadas de sua chegada ao Brasil, o libanês estava de posse de três fazendas.

A trajetória de Feres não é habitual e isso a torna interessante. Ele começa pela mascateação, mas logo a abandona: "gostava de trabalhar na terra". Sem recursos para adquirir uma propriedade, passa a ser arrendatário, mas logo percebe que seria mais lucrativo comercializar frutas e, a partir de então, seu negócio se desenvolve, conduzindo-o à condição de comerciante e fazendeiro em um espaço de tempo relativamente curto.

Outro percurso significativo, porque condensa uma espécie de síntese das possibilidades de mobilidade oferecidas, é o do libanês José Tanus Gastin. Em seu depoimento, ele relatou sua trajetória de mascate no interior até ser industrial na capital:

Logo que cheguei fui para Avaré, onde meus irmãos tinham comércio; fiquei oito dias lá e depois vim embora para Salto Grande [...] Quando comecei a mascatear, meus irmãos me davam mercadoria para vender, e depois que eu vendia pagava para eles [...] Eu mascateava, saía para mascatear [...] Eu não tinha dinheiro, tinha que pegar o pacote e sair vendendo para um ou para outro. Entrava no meio da mata, pensa que eu ficava dentro da cidade? Entrava na mata, andava sete, oito dias a pé, dormia nos paióis, nas matas; às vezes chegava na casa de alguém que não tinha lugar, dormia no paiol, em cima do milho; até, uma vez, um rato me mordeu os pés [...] Eu dormia onde podia, eles me davam comida, leite, me tratavam muito bem [...] Mudei em 1914 de Salto Grande 
para Palmital. Lá eu me estabeleci, pus um botequim e comecei a trabalhar. [Casou com prima irmã, importada do Líbano, em 1921]. Fiquei até 22. Depois, em 23, fui para Presidente Bernardes; era mato, tudo era mato. Montei lá uma loja de tecidos, açúcar, farinha, de tudo. Em 28, comprei uma máquina alemã para beneficiar arroz e também uma máquina de café. Construí prédio e fiquei lá até 41 [...] Eu fiquei no comércio até 41 e depois vim para São Paulo e comprei uma fábrica, uma indústria de seda. Era a mesma coisa, a fábrica não é comércio? Os meus filhos nasceram todos em Presidente Bernardes e em 41 vieram todos para São Paulo. Eu queria dar estudo para os meus filhos e lá não tinha condições [...] Aconteceram dois desastres em minha vida: em 32, queimaram as máquinas de beneficiamento, e o armazém de arroz estava lotado. Eu fiquei sem nada. Depois construí as máquinas novamente [...] Mas, em 40, me queimou a máquina outra vez, me acabou com tudo. Fiquei desgostoso e vim embora. (GREIBER et al., 1998, p. 270-1)

Mascate, dono de botequim, lojista de tecidos e mercadorias em geral, beneficiador, cerealista e finalmente industrial na capital - a impressionante trajetória de Gastin ao longo de sua vida retrata as diferentes opções que a sociedade paulista oferecia à colônia síria e libanesa no interior.

No interior do estado, o comércio miúdo de mercadorias de consumo popular praticado por sírios e libaneses comumente se desdobrou, à medida que prosperou, no comércio cerealista, a exemplo do que apurou Nunes (1996) no estado de Goiás, onde o enriquecimento de membros da colônia efetivou-se pelo comércio atacadista de cereais, principalmente arroz.

\section{Lideranças em integração}

Claro está que, ao longo deste percurso, as possibilidades de mobilidade foram distintamente aproveitadas pelas famílias, o que desde logo implicou diferenciações sociais no interior da colônia. Desse modo, nos municípios onde a colônia era mais numerosa, frequentemente os sírios e libaneses trataram de se organizar em associações étnicas. Em Rio Preto, após várias tentativas frustradas, uma primeira associação foi fundada em 1913, mas que teve vida efêmera. Anos mais tarde, em setembro de 1922, foi fundada a Sociedade Jovens Syrios. Antes meramente recreativa, em 1928, esta associação mantinha o Collegio Jovens Syrios e um serviço de proteção a indigentes, o que determina ser

"[...] quasi impossivel ver um mendigo de nacionalidade syria vaguear pelas ruas da cidade". Presidida por João Gabriel, irmão de Nagib Gabriel, adiante referido, Castanheira apresentou-a em seu álbum com tendo, por objetivo, "manter cohesa e uniforme a unidade syria, ampliando-lhe as dimensões moraes perante o nosso povo, ao qual vive radicada de um modo sincero e sympathico [...]" (CHOEIRI, 1929)

O memorialista Ruy Menezes (1985, p. 73), ao traçar a história do desenvolvimento de Barretos, concluiu que "os árabes, sírios e libaneses, gente a quem muito deve a cidade, também aportaram em seguida, reformulando então toda a estrutura de nosso comércio". A esse respeito, não é demais mencionar a fundação da Sociedade União Síria de Barretos, 
sob a liderança de Abrão Atala, ainda em 1915, e também que esta cidade abrigou o Ginásio Sírio-Brasileiro, fundado pelo Prof. Habib Khodor, e depois transferido para Araraquara (MENEZES, 1985, p. 198). ${ }^{13}$

Em Piracicaba, 28 membros da colônia local, reunidos na casa do Sr. Mansur Elias Zina, fundaram em 1902 a Sociedade Beneficente Syria, cujos objetivos eram

[...] promover a harmonia, a união e o congraçamento dos corações, defender o nome da

Syria e preservar sua honra, eliminar qualquer desentendimento que porventura possa surgir no meio da coletividade e entre os seus membros e prestar apoio a todo aquele cujas condições de vida entram em colapso. (DEZAN, 2012)

Na segunda reunião, ocorrida 11 dias depois, os 36 participantes elegeram a primeira diretoria da associação. Estes quatro objetivos - congraçar, eliminar conflitos internos, zelar pela imagem externa e praticar atividades de benemerência - estruturaram inicialmente a maior parte das associações étnicas do grupo. Mais tarde, as sociedades também serviram de palco de projeção e disputa entre lideranças étnicas que buscavam reconhecimento e prestígio entre os seus.

Fora da colônia, aos poucos tais lideranças foram ocupando postos de relativo prestígio. Dada a "vocação" comercial do grupo, não foi difícil que, ao longo dos anos, sírios e libaneses passassem a ocupar cargos nas associações comerciais locais, como ocorreu, por exemplo, em Ribeirão Preto, com Amin Calil, e em São José do Rio Preto, com Nagib Gabriel, este louvado como "a mais forte organização mental de nosso mundo econômico". ${ }^{14}$

Ainda em Rio Preto, convém explorar uma destas lideranças significativas, o libanês Murchid Homsi (1895-1959), nascido em Hasbaya e que chegou ao Brasil em 1910, estabelecendo-se inicialmente em José Bonifácio como comerciante, onde foi o maior fornecedor dos lavradores da região. Nessa cidade, deixou marcada a sua passagem por meio de uma obra de grande significação econômica: a abertura de uma estrada carroçável de 20 quilômetros ligando José Bonifácio a Rio Preto. Transferindo-se para Rio Preto, Murchid dedicou-se ao comércio e à agricultura e, posteriormente, ao ramo industrial. No comércio e na agricultura, ele dominou os ramos do café, algodão e cereais, os quais produzia, beneficiava, comprava, vendia e exportava. Sempre no setor agroindustrial, fundou várias empresas em sociedade com seus irmãos e com outros, além de servir de ponte a empresários da colônia da capital que investiram na cidade. É considerado "o pioneiro da industrialização de Rio Preto” (GOMES, 1975, p. 401). Em 1948, Murchid Homsi inaugurou o Cotonifício Rio Preto, "uma grande fábrica para produzir e exportar plumas em fio

\footnotetext{
13 Já a União Beneficente Muçulmana de Barretos foi fundada em 1945.

${ }^{14}$ Além de presidir a Associação Comercial de Rio Preto entre 1925 e 1927, Nagib Gabriel era filho de pais sírios e nasceu em Guariba (então distrito de Jaboticabal) em 1890. Em 1908, associou-se ao comércio de seus irmãos em Rio Preto (Casa Esperança e Engenho Esperança). Logo adquiriu propriedades rurais. Ocupou o cargo de delegado de polícia, como maçom presidiu a Loja Cosmos por vários anos e se envolveu em inúmeras iniciativas de cunho filantrópico e beneficente (CAVALHEIRO, 1929). Amin Antonio Calil, filho de imigrante, nasceu em 1910 em Altinópolis, formou-se na Faculdade de Farmácia de Ribeirão Preto e construiu ao longo de sua trajetória de comerciante a rede de lojas A Modelar, com mais de 20 estabelecimentos. No início dos anos 1940 presidiu sucessivamente a Associação Comercial e Industrial de Ribeirão Preto e o Sindicato do Comércio Varejista da região (PRATES, 1981).
} 
de algodão para a Argentina" (ARANTES NETO, 2001, p. 149) e no início dos anos 1950 administrava um conglomerado de dez empresas.

Murchid Homsi no "setor social" (sic) ligou-se a todas as instituições existentes em Rio Preto, tendo sido fundador de muitas delas, entre as quais a Associação Comercial, Industrial e Agrícola (da qual foi seu tesoureiro por muitos anos), o Clube Monte Líbano ${ }^{15}$ (seu presidente honorário e o principal artífice da construção da atual sede), o Rotary Clube (tesoureiro em diversas gestões) e o Jockey Clube, no qual foi sócio fundador. Ainda conforme relata Gomes (1975), no "campo assistencial” (sic), foi tesoureiro e provedor da Santa Casa de Misericórdia por mais de dez anos, ao passo que sua esposa presidiu a Legião Brasileira de Assistência em Rio Preto. Por fim, “em janeiro de 1958, por decreto do Presidente do Líbano, Camille Chamoun, recebeu na Chancelaria da Embaixada do seu país, no Rio de Janeiro, o título de Cônsul Honorário do Líbano" (GOMES, 1975, p. 401).

A trajetória de Homsi indica que este personagem logrou acumular, ao longo de quase meio século (chegou em 1910 e faleceu em 1959) de sua vida no Brasil (mais especificamente na região de São José do Rio Preto), um portfólio bastante significativo de capitais não apenas econômicos, mas também sociais. Porém, ele não foi o único da colônia a lograr tais conquistas, o que nos conduz ao tema da aproximação entre tais estratos da elite étnica às elites oligárquicas tradicionais das cidades interioranas.

As famílias bem-sucedidas, após acumularem fortunas consideráveis no comércio interiorano, tenderam também, como já mencionado, a se tornarem proprietárias de fazendas. Nelly Alasmar recordou que seu pai "vendeu a loja e comprou uma parte da fazenda Santa Sofia, que era de uma das herdeiras do Conde do Pinhal [...] Então, papai se tornou fazendeiro e não se meteu mais no comércio, levou vida de fazendeiro" (GREIBER et al., 1998, p. 252). Ela também se recorda das distâncias sociais entre sua própria família e as das elites tradicionais de Jaú, ainda que o meio interiorano favorecesse a convivência das crianças em espaços públicos. Inicialmente, diz ela,

[...] não havia convite de parte a parte. Mamãe frequentava as casas deles para negócios. Sociedade, não. Nem eles vinham na nossa casa e nem eu ia na casa deles. Nós nos encontrávamos, fazíamos vida em comum no colégio. Bom, na pracinha da matriz eu brincava com esse pessoal todo. (GREIBER et al., 1998, p. 254)

Referindo-se à sociabilidade entre as famílias de seu grupo étnico, ela acrescenta:

[...] havia amizade muito grande entre as famílias, aquelas famílias antigas. A gente formava quase uma colônia mesmo. Eram sírios e libaneses, não tinha distinção, tudo era uma coisa só [...] Era um núcleo. Depois é que os filhos foram casando e houve o entrelaçamento, aí sim, entre brasileiros e sírios [...] Na nossa época, não... até tem a história de um patrício que se casou com uma brasileira [...] Chamava-se Felício Tarabai. Quando ele se apaixonou por uma Junqueira, e ela por ele, vieram fugidos e foram ficar lá em casa, na fazenda, em Jaú. Os Junqueira queriam matar o Tarabai... Foi mamãe que fez eles se casarem. (GREIBER et al., 1998, p. 254)

\footnotetext{
${ }^{15}$ Além da capital, existiu também um clube Monte Líbano em Franca, fundado em 1955 e fruto da dissenção de membros libaneses outrora sócios da Sociedade União Síria Beneficente (COELHO, 1998, p. 100 e 117).
} 
Lydia Tabet Stefanini recorda-se de ter resistido bravamente às investidas de seu tio, que com ela queria se casar. Ela, porém, gostava de um "italiano" e teve que enfrentar a resistência não apenas de sua família ao casamento, mas também das jovens concorrentes em Presidente Alves, no extremo oeste paulista:

[...] onde eu me casei me chamavam de Turquinha, eu tinha uma raiva! Hoje é bonitinho, mas naquele tempo a gente tinha um pouco de complexo. Sabe como é em cidade pequena, eu tinha amigas contra mim, assim por causa do namorado, então quantos bilhetinhos eu vi que mandavam para o Stefanini: 'O que você vê nesta Turquinha?, é uma raça ruim, malvada, raça que toma sangue de gente...' Eu ficava com uma raiva! (GREIBER et al., 1998, p. 284)

Mormente nos círculos das elites, em matéria de matrimônio, os padrões endogâmicos permaneceram por décadas e é interessante observar que as restrições e resistências provinham sobretudo da colônia: "olha, vou dizer: até hoje muitas famílias não aceitam casamento com brasileiros. Brasileiro ainda facilita. Mas o patrício não é com muita satisfação que vê um filho se casar fora da colônia. Não é uma satisfação" (GREIBER et al., 1998, p. 254).

Aos poucos, entretanto, a bem-sucedida trajetória de algumas famílias sírias e libanesas acabou aproximando elites de estratos diversos e forjando alinhamentos, cujo sentido pautou-se menos pelo crivo étnico e mais pela classe social. Assim, por exemplo, Elias Alasmar rememorou o modo como sua família foi aceita no aristocrático clube local.

Antigamente, o Jaú Clube não aceitava estrangeiros... era um clube fechado, dos Almeida Prado, Pacheco, não aceitavam estrangeiros de jeito nenhum [...] Fomos os primeiros que o Jaú Clube admitiu como sócios [...] isso mais ou menos em 1937. Quando fui convidado para ser sócio eu disse; 'Por quê? Num clube que não posso levar minha mãe eu não entro!' Falei na lata. Resolveram mudar os estatutos, me convidaram e eu entrei [...] Mas viviam chamando a gente de turco lá. Turco, turco, turco. É. No sentido pejorativo mesmo. Mas eles eram muito ignorantes. Porque eles não conhecem nossa origem. Mas eu, quando me chamaram de turco, disse: ‘Muito bem'. Estava reunida lá a fina flor dos Almeida Prado. Eu disse: 'Bom, eu sou turco, muito bem. Sou turco e o meu nome é Alasmar. Você sabe o que quer dizer Alasmar? Alasmar quer dizer 'o moreno', al asmar. Agora, vocês sabem qual a origem de vocês? Vocês são Almeida, vocês são de origem árabe. Vocês sabem o que quer dizer Almeida?' Estavam todos os Almeida lá. 'Eu vou explicar para vocês o que é.' E continuei falando para eles: 'A origem do nome que vocês carregam até hoje, Almeida, vem do árabe Al Maida, Almaida, Almeida. Quer dizer a mesa de comer; quer dizer que a origem e a nobreza de vocês vêm da nossa cozinha, enquanto que a minha pigmentação é minha origem, a minha nobreza. Vocês todos serviram à mesa como garçons ou faziam a nossa comida na cozinha. São os Almeida'. Nunca mais me chamaram de turco. (GREIBER et al., 1998, p. 252-3)

\section{Práticas religiosas}

Outro ponto que merece menção é a questão religiosa, um dos pilares fundamentais da identidade dos imigrantes sírios e libaneses. Ao mesmo tempo que a filiação religiosa 
comum de cristãos favoreceu a integração da maioria dos imigrantes árabes no Brasil, ${ }^{16}$ deve-se também ressaltar a perda histórica de fiéis das igrejas próprias da comunidade árabe para o catolicismo, dotado de uma estrutura muito mais capilar ao tecido social brasileiro, presente em qualquer povoação por menor que ela fosse. Assim, a falta de instituições religiosas próprias no interior resultou em um processo de adesão ao catolicismo romano (TRUZZI, 2016). “Como não havia igreja ortodoxa em Rio Bonito, meus pais frequentavam a igreja católica. Meu pai nunca fez diferença entre a Igreja Católica e a Igreja Ortodoxa" (GREIBER et al., 1998, p. 365). Em Jeriquara, próxima a Pedregulho, Nasri Machoul, proveniente da Síria e de religião cristã ortodoxa, frequentava a igreja católica e matriculou seu filho em um colégio de padres católicos, afirmando não haver nenhum problema nisso, uma vez que "as duas religiões se confundem". Coelho (1998, p. 91) apurou que

[...] os ortodoxos tiveram que agir assim porque não havia padres ortodoxos na região. Quando um padre ortodoxo visitava seus fiéis, as pessoas aproveitavam para batizar 3 ou 4 crianças e realizar casamentos. Essas visitas eram motivo para a realização de muitas festas que reuniam pessoas de diversos lugares da região.

Em Altinópolis, Rosa (2001b, p. 84) observou que apenas na primeira geração era comum "batizar os filhos com o padre ortodoxo, que uma vez por ano vinha da cidade de Guaxupé-MG realizar o batismo e às vezes até os casamentos da comunidade árabe”.

No mesmo sentido, Claude Hajjar (1985, p. 77) observou que

[...] milhares de imigrantes, estabelecendo-se em pequenas cidades e povoados, perderam muitos de seus hábitos originais, muitos deles fizeram-se católicos, pois não havia outro culto na coletividade. Um grande número, entretanto, aderiu à fileira dos incrédulos. Foi somente nas grandes cidades como São Paulo, Rio de Janeiro ou outras que os diferentes cultos tiveram um local adequado para suas pregações.

A este respeito, são significativas as circunstâncias da organização da igreja ortodoxa em São José do Rio Preto. Segundo Martins, a maioria dos imigrantes de origem árabe desta região do interior paulista era composta por ortodoxos e maronitas. A princípio, nenhum dos dois grupos sentiu necessidade de construir sua própria igreja, visto que o contexto católico romano vigente na região lhes pareceu suficientemente familiar. Contudo, a o final dos anos de 1920, aconteceu um episódio no qual o pároco local se recusou a encomendar o corpo de um ortodoxo falecido na cidade. "Depois disso, houve discussão no jornal da cidade entre o padre e um patrício, Elias Choeiri” (MARTINS, 2009, p. 67). A polêmica arrastou-se por alguns anos, com as posições polarizadas, pois em fevereiro de 1934 o jornal local $A$ Notícia advertiu na coluna Vida Catholica que "as pessoas de vida publicamente escandalosas, os orthodoxos syrios que pertencem a seitas condemnadas pela Igreja, e os casados apenas no civil não podem ser padrinhos" (MARTINS, 2009, p. 68) dos crismados.

\footnotetext{
${ }^{16}$ É plausível também que a frequência ao culto católico, assim como a sociedades maçônicas, servisse como elemento de aproximação dos sírios e libaneses às elites locais, potencializando uma integração mais rápida, conforme sugeriu Coelho (1998).
} 
Como era de se esperar, a advertência gerou reações na comunidade sírio-libanesa, ultrajada pela atitude supostamente tomada pelo pároco. Artigos escritos por ortodoxos sírios e publicados no mesmo jornal lembraram que estes "só fizeram bem à Igreja local”, mencionando o seu apoio em inúmeras ocasiões, como a criação do bispado, a construção da catedral, a oferta do relógio da torre da igreja e do madeiramento de toda a cobertura de outra igreja, entre outros. Estranhou-se ainda que a advertência se aplicava apenas a ortodoxos sírios, e não a libaneses, russos, armênios, gregos, etc. Por fim, os artigos exortavam os patrícios "indignados e feridos nos seus legítimos sentimentos [...] que sempre que forem convidados para servirem de padrinhos frisem bem e com todo o orgulho serem adeptos do Rito Orthodoxo" (MARTINS, 2009, p. 78).

A partir de tais episódios, os ortodoxos se organizaram e fundaram uma igreja própria: reunidos no dia 8 de fevereiro de 1934, deliberaram pela edificação de uma igreja ortodoxa (GOMES, 1975, p. 214).

A partir de então, as providências sucederam-se para a compra de um terreno e montagem de uma comissão para construção da igreja (setembro de 1934), vinda do primeiro padre ortodoxo ao município (agosto de 1935) e lançamento da pedra fundamental do edifício (novembro de 1936), que seria inaugurado 11 anos mais tarde, em 1947, com a presença dos arcebispos metropolitanos de Zahle, no Líbano, e de Hama, na Síria, do recém-eleito governador do estado Adhemar de Barros, seu secretariado e grande comitiva de autoridades. Tal reação só se mostrou viável em um centro como Rio Preto, porque ali o volume da comunidade sírio-libanesa era muito expressivo. Caso algo semelhante tivesse se passado em municípios menores, provavelmente teríamos outro desfecho.

\section{Mobilidade social da primeira geração: doutores e políticos}

A primeira geração de sírios e libaneses, já nascida no interior paulista, contou com um horizonte de possibilidades mais ampliado. Desde logo, havia a opção de continuar e ampliar os negócios da família, o que por si já significava uma alternativa de como ganhar a vida. Nesses casos, normalmente a "formação profissional" ocorria sur le tas, isto é, no próprio negócio familiar, embora algumas vezes envolvesse experiências externas, como relatou Michel Naffah:

Eu trabalhei de criança com meus pais, mas meu pai tinha uma coisa interessante nele: tinha uma loja enorme, mas se o patrício da esquina tinha uma loja maior, se o patrício da esquina tinha possibilidade de me ensinar mais coisas, ele dizia assim: 'Vai trabalhar com ele'. Você compreendeu? E foi justamente indo trabalhar num armazém de atacado, onde trabalhavam centenas de pessoas, que o contador de lá certa vez me disse - isso em 1934: 'Naffah, você sabe fazer uma conta corrente, sabe fazer um livro-caixa, sabe fazer um borrador? Compra um joguinho de livros que eu vou te ensinar contabilidade'. (GREIBER et al., 1998, p. 310) 
Importa também ressaltar que, em decorrência da mobilidade socioeconômica obtida pelos imigrantes sírios e libaneses e do desejo ardente destes formarem seus filhos como doutores, a colônia passou a contar com muitos diplomados no interior, em carreiras das profissões liberais. “Em São José do Rio Preto tem uma colônia muito grande: eu acredito que só de médico e advogado oriundos de famílias árabe e libanesa deve ter algumas dezenas..." (GREIBER et al., 1998, p. 310). ${ }^{17}$ "Formados no Brasil, temos legiões de jovens de ambos os sexos Syrios e Brasileiros de paes Syrios, como sejam medicos, advogados, engenheiros, dentistas, pharmaceuticos, guarda-livros e professores" (CHOEIRI, 1929).

Era até certo ponto natural então que, sendo suas famílias conhecidas como comerciantes e tendo se formado como doutores, as vias de uma carreira política se tornassem atrativas. Foi o que muitos filhos de imigrantes fizeram, elegendo-se como vereadores e prefeitos, sobretudo a partir da redemocratização do país na segunda metade dos anos 1940. E como consequência de carreiras políticas iniciadas como vereador ou prefeito em cidades do interior paulista, vários destes políticos tiveram sucesso em pleitear cargos na Assembleia Legislativa estadual e mesmo na Câmara Federal nos anos 1950. Entre estes, Bady Bassit, Semi Jorge Resegue, Nagib Chaib, Miguel Jorge Nicolau e Anibal Hamam - todos muito pouco conhecidos na capital paulista, mas que portavam um traço distintivo comum. Eles haviam ocupado cargos políticos em suas cidades de origem e, agora, convertiam a popularidade acumulada em suas bases interioranas em trunfos eleitorais: Bady Bassit na região de São José do Rio Preto; Semi Jorge Resegue em Bariri; Nagib Chaib em Mogi Mirim; Miguel Jorge Nicolau em São João da Boa Vista; e Anibal Hamam em Pirajuí.

Em 1962, tal padrão de recrutamento político no interior, dominante para descendentes de sírios e libaneses eleitos, se aprofundou com as eleições de José Jorge Cury, com base em São José do Rio Preto, Jamil Assuf Dualibi em Tupã, Nadir Kenan em Barretos, Jamil Gadia em Campinas, Nabi Abi Chedid em Bragança Paulista, além de Jayme Daige em Guarujá, vários deles reeleitos em 1966. 0 mesmo ocorreu no plano federal: Tufy Nassif, eleitoralmente forte em Franca; Pedro Marão, em Araraquara; Aniz Badra, em Marília; Paulo Jorge Mansur, em São Vicente - todos também vitoriosos em 1966. Tal recrutamento interiorano se manteve como o padrão dominante e, em boa parte, explica a elevada representação de descendentes de sírios e libaneses no campo político, fruto da combinação peculiar de dois fatores: a inserção urbana e o padrão geográfico de dispersão da colônia, originalmente tributário da atividade de mascates, ou, em última análise, da convicção de que qualquer lugarejo constituía um mercado em potencial para o mascate se fixar como comerciante. Tais fatores, acoplados a uma mobilidade ascensional forte, possibilitada pelo investimento educacional na segunda geração, muito rapidamente agiram como elementos que impulsionaram a emergência de lideranças locais (TRUZZI, 2008a).

Uma amostra parcial e meramente ilustrativa da afluência de políticos descendentes de sírios e libaneses no interior pode ser avaliada pelo Quadro 1.

\footnotetext{
${ }^{17}$ Já em 1928, o Álbum da Comarca de Rio Preto destaca, por exemplo, os doutores H. Garzuzi e Taukik Rahd como “médicos da colônia syria".
} 
QUADRO 1

Patrícios do interior na política paulista (32 mandatos de deputados estaduais e federais eleitos entre 1954 e 1966)

\begin{tabular}{|c|c|c|c|c|}
\hline Ano & $\begin{array}{l}\text { Cargo/legenda/cargo } \\
\text { político anterior }\end{array}$ & Nome & Curso superior/profissão & $\begin{array}{l}\text { Base eleitoral } \\
\text { de origem }\end{array}$ \\
\hline 1954 & D. est./PSP & Bady Bassit & Médico & S.J. Rio Preto \\
\hline 1958 & D. est./PSP & Semi J. Resegue & $(\star)$ & Bariri \\
\hline 1958 & D. est./PDC/ver. (47-51) & Nagib Chaib & Comerciante & Moji Mirim \\
\hline 1958 & D. est./PTB/pref. (56-58) & Miguel Nicolau & $(*)$ & S.J. Boa Vista \\
\hline 1958 & D. est./PTB/pref. & Anibal Hamam & Advogado & Pirajuí \\
\hline 1962 & D. fed./PTB/pref. & José J. Resegue & Fac. Medicina RJ & Bariri \\
\hline 1962 & $\begin{array}{l}\text { D. fed./PDC/d. fed. (34-37)/ } \\
\text { ver. }(47-58)\end{array}$ & Aniz Badra & Fac. Direito RJ (1945) & Marília \\
\hline 1962 & D. fed./CJ//ver. (54-62) & Tufy Nassif & Técn. contábil/func. públ. & Franca \\
\hline 1962 & D. fed./CJ/ver. & Pedro Marão & Fac. Odont (46) Dir. Niterói (51) & Araraquara \\
\hline 1962 & $\begin{array}{l}\text { D. est./PDC/ ver. (47-51) } \\
\text { d. est. (58-62) }\end{array}$ & Nagib Chaib & Comerciante & Mogi Mirim \\
\hline 1962 & D. est./PSP/d. est (58-62) & Semi J. Resegue & $(*)$ & Bariri \\
\hline 1962 & D. est./PSP/ver. (52-60) & José J. Cury & Fac. Direito Bauru (1957) & S.J. Rio Preto \\
\hline 1962 & D. est./PRT/pref. (54-57) & Jamil Dualibi & Fac. Direito Bauru & Tupã \\
\hline 1962 & D. est./CJ/ver. (55-62) & Nadir Kenan & Fac. Dir. RJ/radialista & Barretos \\
\hline 1962 & D. est./CJ/ver. (56-62) & Jamil Gadia & Pres. sind./Guarani FC & Campinas \\
\hline 1962 & $\begin{array}{l}\text { D. est./PRP/ pres. Bragantino } \\
\text { FC }\end{array}$ & Nabi A. Chedid & Advogado & Bragança Paulista \\
\hline 1966 & $\begin{array}{l}\text { D. fed./MDB/ ver. Araraq. } \\
\text { d. fed. }(62-66)\end{array}$ & Pedro Marão & $\begin{array}{l}\text { Fac. Odont. (46) Dir. Niterói } \\
\text { (51) }\end{array}$ & Araraquara \\
\hline 1966 & $\begin{array}{l}\text { D. fed./Arena/pref. Bariri } \\
\text { d. fed. }(62-66)\end{array}$ & José J. Resegue & Fac. Medicina RJ & Bariri \\
\hline 1966 & $\begin{array}{l}\text { D. fed./Arena/ d. fed. (62-66), } \\
\text { ver. (47-58) }\end{array}$ & Aniz Badra & Fac. Direito RJ (1945) & Marília \\
\hline 1966 & $\begin{array}{l}\text { D. fed./Arena/ ver. (54-62), } \\
\text { d. fed. }(62-66)\end{array}$ & Tufy Nassif & Técn. contábil/func. públ. & Franca \\
\hline 1966 & $\begin{array}{l}\text { D. est./Arena/ ver. (47-51), } \\
\text { d. est (58-66) }\end{array}$ & Nagib Chaib & Comerciante & Mogi Mirim \\
\hline 1966 & D. est./Arena/d. est. (58-66) & Semi J. Resegue & $(*)$ & Bariri \\
\hline 1966 & $\begin{array}{l}\text { D. est./Arena/ ver.(52-60), } \\
\text { d. est. (62-66) }\end{array}$ & José J. Cury & Fac. Direito Bauru (1957) & S.J. Rio Preto \\
\hline 1966 & $\begin{array}{l}\text { D. est./Arena/ pref. (54-7), } \\
\text { d. est. }(62-66)\end{array}$ & Jamil Dualibi & Fac. Direito Bauru & Tupã \\
\hline 1966 & $\begin{array}{l}\text { D. est./MDB/ver. (55-62), } \\
\text { d. est. (62-66) }\end{array}$ & Nadir Kenan & Fac. Dir. RJ/radialista & Barretos \\
\hline 1966 & $\begin{array}{l}\text { D. est./MDB/ver. (56-62), } \\
\text { d. est. (62-66) }\end{array}$ & Jamil Gadia & Pres. sind./Guarani FC & Campinas \\
\hline 1966 & $\begin{array}{l}\text { D. est./Arena/pres. BFC, } \\
\text { d. est. (62-66) }\end{array}$ & Nabi A. Chedid & Advogado & Bragança Paulista \\
\hline 1966 & D. est./MDB/ pref. (60-64) & J. Maluly Neto & Fac. Medicina RJ (1956) & Mirandópolis \\
\hline 1966 & D. est./Arena/( $\left.{ }^{\star}\right)$ & Ant. S. Curiati & Esc. Paul. Medicina (1953) & Avaré \\
\hline 1966 & $\begin{array}{l}\text { D. est./Arena/ pres. Soc. Paul. } \\
\text { Agronomia }\end{array}$ & José Calil & E.S. Agr. Luiz Queiróz (39) & Piracicaba \\
\hline 1966 & D. est./Arena/(*) & Nesralla Rubes & Advogado & Cruzeiro \\
\hline 1966 & D. est./Arena/ver. (56-66) & Salim A. Thome & Comerciante & Barretos \\
\hline
\end{tabular}

Fonte: Truzzi (2008a, p. 202-210).

(*) Dado não apurado. 
Salta aos olhos a presença maciça de personagens que entraram na política estadual e federal, a partir de carreiras iniciadas em cidades interioranas. É preciso ter-se em conta que os dados apresentados no Quadro 1 apontam apenas os candidatos eleitos a cargos de deputados estadual e federal entre 1954 e 1966. Um número muito maior de descendentes de sírios e libaneses foram apenas candidatos que não tiveram êxito, ou ainda que restringiram sua atuação política ao âmbito local, seja como vereadores ou como prefeitos de cidades do interior, a exemplo de Miguel Vicente Cury, filho de imigrantes, que cumpriu significativa carreira política em Campinas, onde sua família era proprietária de uma das maiores fábricas de chapéus.

\section{Considerações finais}

Embora traços comuns possam ser observados entre as relativamente bem-sucedidas trajetórias de sírios e libaneses na capital e no interior - a inserção inicial como mascate, a rejeição ao colonato e decorrente implantação urbana, além do apoio familiar e de uma rede de conterrâneos (TRUZZI, 2008a, p. 63-69) -, este artigo procurou explorar algumas características específicas de sírios e libaneses no oeste paulista.

Em termos espaciais, a concentração mais notável ocorreu no extremo noroeste do estado, em municípios ao redor de São José do Rio Preto, justamente por esta cidade ter se constituído como ponto estratégico de distribuição de mercadorias para o interior de São Paulo e para outros estados, dada sua condição de "ponta de linha" (de estrada de ferro) ao longo de mais de duas décadas.

Em vários municípios do interior paulista, também chama a atenção a ocorrência de concentrações de imigrantes de determinadas localidades na origem, o que denota a importância das redes que promoveram a importação de famílias aparentadas ou vizinhas, como já se observou. Além de incentivarem a vinda propriamente dita de imigrantes, as redes exerceram papel relevante no acolhimento destes e na superação das dificuldades iniciais, seja pela introdução prática ao novo idioma, seja pelo provimento de mercadorias e crédito para o recém-chegado se estabelecer.

É notável, por outro lado, a importância que as populações rurais (instaladas nas fazendas sob o regime do colonato) tiveram como clientela para os vendedores ambulantes de origem síria e libanesa, mormente nos ramos tradicionais de armarinhos, têxtil e de confecções, explorados pelo imigrante desta origem ao trazer mercadorias da capital. Além disso - e este constituiu um traço distintivo do oeste paulista -, a trajetória econômica trilhada também evoluiu para a instalação tanto de armazéns que comercializavam excedentes da lavoura, quanto de máquinas de beneficiamento de produtos agrícolas, em geral combinadas estas duas atividades.

Embora obviamente possam existir casos de mobilidade descendente, é evidente, sobretudo tomando-se como ponto de partida a inserção inicial como mascates, que o saldo da mobilidade revelou-se amplamente positivo, potencializado não apenas pelo sucesso 
dos negócios nos ramos anteriormente apontados, mas principalmente pela entrada de estratos de segunda geração nas profissões liberais (e daí para a ocupação de cargos políticos). Pelo material levantado, conviria ainda pontuar que, com o passar do tempo, o alcance da condição de fazendeiro ou de grande proprietário de imóveis urbanos sempre esteve subordinado ao sucesso das atividades comerciais.

Foi possível também apurar que em municípios do interior paulista que contavam com contingentes menos numerosos de imigrantes desta origem, a conversão ao catolicismo foi quase um imperativo, dada a dificuldade de seguirem praticando seus credos originais. Já nos municípios onde a colônia era mais densa, os sírios e libaneses organizaram-se tanto em termos religiosos, quanto em associações étnicas. Ambos, com o tempo, projetaram lideranças (em geral economicamente bem-sucedidas) dispostas a realizar a intermediação com a sociedade mais abrangente, e que serviam de "demonstração do valor da raça", tal qual exemplificado pelo caso de Murchid Homsi, aqui explorado.

Em face das trajetórias relativamente bem-sucedidas no interior paulista, não foi difícil para os sírios e libaneses se regozijarem do acerto da empreitada migratória. "Aqui fui muito bem recebida”, pontuou Rania Haddad em sua entrevista já mencionada. "Cheguei no dia 2 de novembro nesta bendita terra brasileira, em Santos. Eu estava para completar dezessete anos" - assim referiu-se José Tanus Gastin em seu depoimento (GREIBER et al., 1998, p. 270). "Eu gostei de tudo, quando cheguei ao Brasil. O povo é muito bom, muito agradável. Acho que, principalmente no interior, o povo é muito bom, muito dado com os outros [...] Eu tinha dezessete anos quando cheguei aqui. Lá no Líbano é muito bom mas eu gosto mais daqui do que de lá”, completou Ahmed Abduni (GREIBER et al., 1998, p. 240-3).

\section{Referências}

ALMEIDA, A. T. Oeste paulista - a experiência etnográfica e cultural. Rio de Janeiro: Alba, 1943. ARANTES NETO, A. Dicionário rio-pretense de A a Z. São José do Rio Preto: Casa do Livro, 2001. BACKEUSER, E. Comércio ambulante e ocupações de rua no Rio de Janeiro. Revista Brasileira de Geografia, v. 6, n. 1, p. 14, 1944.

BASSANEZI, M. S. et al. Atlas da imigração internacional em São Paulo. São Paulo: Ed. Unesp, 2008.

BASTANI, T. J. O Líbano e os libaneses no Brasil. Rio de Janeiro: Estabelecimento de Artes Gráficas, 1945.

BASTOS, W. de L. Os sírios em Juiz de Fora. Juiz de Fora: Edições Paraibuna, 1988.

BRANDÃO, G. A. Sírios e libaneses em Cuiabá: imigração, especializações e sociabilidade. Dissertação (Mestrado) - Universidade Federal do Mato Grosso (UFMT), Cuiabá, 2007.

BRANDI, A. São José do Rio Preto: 1894-1907 - o ciclo dos intendentes e a criação da comarca. São José do Rio Preto: THS Editora, 2012.

BRASIL. Ministério da Agricultura, Industria e Commércio. Recenseamento do Brazil 1920. Rio de Janeiro: TYP da Estatística, 1922. 
CABREIRA, M. M. Cultura e identidade em São Paulo: a imigração síria e libanesa. EccoS Revista Científica, São Paulo, v. 3, n. 1, p. 93-103, 2001. Disponível em: 〈http://www.redalyc.org/articulo. oa?id=71530107〉. Acesso em: 17 maio 2019.

CAMPOS, M. A. Turco pobre, sírio remediado, libanês rico: trajetória do imigrante libanês no Espírito Santo. Vitória: Instituto Jones dos Santos Neves, 1987.

CAVAlHeIRO, A. (org.). Album Illustrado da Comarca de Rio Preto 1927-1929. São Paulo: Casa Editora Duprat-Mayença, 1929.

CHOEIRI, E. Colonia Syria em Rio Preto. In: CAVALHEIRO, A. Album Illustrado da Comarca de Rio Preto 1927-1929. São Paulo: Casa Editora Duprat-Mayença, 1929.

COELHO, H. M. F. Imigração e história local: sírios e libaneses em Franca. Tese (Livre Docência) Faculdade de História, Direito e Serviço Social/Universidade Estadual Paulista Júlio de Mesquita Filho (FHDSS/Unesp), Franca, 1998.

DEFFONTAINES, P. Mascates ou pequenos negociantes ambulantes do Brasil. Geografia, v. 2, n. 1, p. 26-29, 1936.

DEZAN, M. D. de S. Impactos das imigrações espanhola e sírio-libanesa como fator para o desenvolvimento econômico e diversidade cultural na organização do espaço geográfico piracicabano. Tese (Doutorado em Geografia) - Instituto de Geociências e Ciências Exatas/ Universidade Estadual Paulista Júlio de Mesquita Filho, Rio Claro, 2012. Disponível em: 〈http:// repositorio.unesp.br/bitstream/handle/11449/104432/dezan_mds_dr_rcla.pdf?sequence=1〉. Acesso em: 17 dez. 2018.

DUOUN, T. A emigração sírio-libanesa às terras de promissão. São Paulo: Tipografia Editora árabe, 1944.

DRUBI, S. Colina, capital nacional do cavalo. Barretos: Sete Virtudes, 2007.

DRUBI, S. Raízes de Jaborandi. Barretos: Soares Barretos, 1998.

FERNANDJES, R. A habilidade árabe no comércio. Diário da Região, São José do Rio Preto, SP, 19 mar. 2008.

FRANCISCO, J. C. B. Dos cedros aos pampas: imigração sírio-libanesa no Rio Grande do Sul, etnicidade e assimilação (1890-1949). Tese (Doutorado em História) - Pontifícia Universidade Católica do Rio Grande do Sul, Porto Alegre, 2017.

GATTAZ, A. Do Líbano ao Brasil: história oral de imigrantes. Salvador: Pontocom, 2012.

GATTAZ, A. História oral da imigração libanesa no Brasil, 1888-2000. Tese (Doutorado) Faculdade de Filosofia, Letras e Ciências Humanas, Universidade de São Paulo (FFLCH/USP), São Paulo, 2001.

GOMES, A. M. Os libaneses em Cajuru. Tese (Doutorado) - Centro Universitário Barão de Mauá, Ribeirão Preto, 2004.

GOMES, L. Gente que ajudou a fazer uma grande cidade - Rio Preto. São José do Rio Preto: Editora Gráfica São José, 1975.

GREIBER, B. L. et al. Memórias da imigração - libaneses e sírios em São Paulo. São Paulo: Discurso Editorial, 1998.

GRISPINO, I. S. Sentimentos de família. Família Feres Sadalla. Ribeirão Preto (edição da autora), 2002.

HAJJAR, C. Imigração árabe: 100 anos de reflexão. São Paulo: Ícone, 1985. 
HITTI, P. K. The Syrians in America. New York: George H. Doran Company, 1924.

JACOB, J. M. Sírios e libaneses: árabes diferentes, brasileiros iguais ou de como a identidade étnica se transforma e se mantém. Monografia (Bacharelado em Ciências Sociais) - Universidade de Brasília, Brasília, 2014.

JORGE, S. Álbum da colônia sírio-libanesa no Brasil. São Paulo: Sociedade Impressora Brasileira, 1948.

KHOURI, J. M. Pelos caminhos de São Paulo: a trajetória dos sírios e libaneses na cidade. Dissertação (Mestrado) - Faculdade de Filosofia, Letras e Ciências Humanas, Universidade de São Paulo (FFLCH/USP), São Paulo, 2013.

KNOWLTON, C. Sírios e libaneses: mobilidade social e espacial. São Paulo: Anhembi, 1961.

KURBAN, T. Os sírios e libaneses no Brasil. São Paulo: Sociedade Impressora Paulista, 1933.

MARTINS, D. Imigração árabe e religiosidade em São José do Rio Preto - Igreja Católica Apostólica Ortodoxa Antioquina: um estudo de caso. Dissertação (Mestrado em Ciências da Religião) Universidade Presbiteriana Mackenzie, São Paulo, 2009.

MENEZES, R. Espiral. História do desenvolvimento cultural de Barretos. Barretos: Instituto Tecnológico e Científico Prof. Roberto Rios (Intec), 1985.

NUNES, H. P. A imigração árabe em Goiás (1880-1970). Tese (Doutorado) - Faculdade de Filosofia, Letras e Ciências Humanas, Universidade de São Paulo (FFLCH/USP), São Paulo, 1996.

OLIVEIRA, M. R. C. Imigração sírio-libanesa em Campo Grande e o Clube Libanês. Dourados: Universidade Federal da Grande Dourados (UFGD), 2010.

PINTO, P. H. Árabes no Rio de Janeiro: uma identidade plural. Rio de Janeiro: Cidade Viva, 2010.

PRATES, P. C. Ribeirão e seus homens progressistas. Ribeirão Preto (edição do autor), 1981.

REGO, M. F. Memória da imigração de sírios e libaneses em Rondonópolis - MT. Dissertação (Mestrado) - Universidade Federal do Mato Grosso (UFMT), Cuiabá, 2006.

RIBEIRO, P. Multiplicidade étnica no Rio de Janeiro: um estudo sobre o 'SAARA'. Acervo, v. 10, n. 2, p. 199-212, 1997.

ROSA, M. D. ‘Fazer a América’: sírios e libaneses em Altinópolis. Amicus, ano II, n. 3, 2001 a.

ROSA, M. D. Memórias da imigração: a trajetória do imigrante sírio-libanês em Altinópolis. Dissertação (Mestrado) - Faculdade de História, Direito e Serviço Social/Universidade Estadual Paulista Júlio de Mesquita Filho (FHDSS/Unesp), Franca, 2001b.

SAFADY, J. S. A imigração árabe no Brasil. Tese (Doutorado). Faculdade de Filosofia, Letras e Ciências Humanas/Universidade de São Paulo (FFLCH/USP), São Paulo, 1972.

SANTOS, M. et al. Migração: uma revisão sobre algumas das principais teorias. Belo Horizonte: Centro de Desenvolvimento e Planejamento/ Universidade Federal de Minas Gerais (Cedeplar/ UFMG, 2010 (Texto para Discussão, n. 398). Disponivel em: 〈https://www.cedeplar.ufmg. br/publicacoes/textos-para-discussao/textos/2010/661-398-migracao-uma-revisao-sobrealgumas-das-principais-teorias>. Acesso em: 6 out. 2019.

SOUZA, R. S. Uma vida entre dois mundos: imigrantes sírios e libaneses em Dourados (1910-1980). Dissertação (Mestrado em História) - Universidade Federal da Grande Dourados, Dourados, MS, 2007.

SOUZA, M. M. C. M. 0 povo da caixa e a 25 de março: memórias da imigração síria e libanesa em São Paulo. Tese (Doutorado) - Faculdade de Filosofia, Letras e Ciências Humanas/Universidade de São Paulo (FFLCH/USP), São Paulo, 2003. 
TRUZZI, O. Patrícios. Sírios e libaneses em São Paulo. 2. ed. São Paulo: Ed. Unesp, $2008 \mathrm{.}$

TRUZZI, O. Redes em processos migratórios. Tempo Social, v. 20, n. 1, p. 199-218, 2008b.

TRUZZI, O. Religiosidade cristã entre árabes em São Paulo: desafios no passado e no presente. Religião \& Sociedade, v. 36, n. 2 p. 266-291, 2016.

VILELA, E. M. Sírios e libaneses. Redes sociais, coesão e posição de status. Revista Brasileira de Ciências Sociais, v. 26, n. 76, p. 157-225, 2011. Disponivel em: 〈http://www.redalyc.org/articulo. oa?id=10719120009>. Acesso em: 17 maio 2019.

WEINSTEIN, B. The color of modernity: São Paulo and the making of race and nation in Brazil. Durham: Duke University Press, 2015.

YKEGAYA, T. Imigração árabe em Foz do Iguaçu: a construção de uma identidade étnica. Dissertação (Mestrado) - Universidade Estadual do Oeste do Paraná, Cascavel, 2006.

\section{Sobre o autor}

Oswaldo Truzzi é doutor em Ciências Sociais pela Universidade Estadual de Campinas (Unicamp). Professor titular do Programa de Pós-Graduação em Sociologia da Universidade Federal de São Carlos (UFSCar).

\section{Endereço para correspondência}

Rua Joaquim da Cruz Penalva, 833, Jd. São João Batista

13566-810 - São Carlos-SP, Brasil

\section{Abstract}

\section{Syrian and Lebanese in Western São Paulo}

The article seeks to explore the conditions and distinctive characteristics of the socioeconomic insertion of Syrians and Lebanese in the interior of São Paulo between the 1880s and 1950s. From the difficult beginning as peddlers with a distant culture, Syrians and Lebanese managed to establish themselves as merchants, seizing the opportunities that their networks (of relatives and of countrymen) and the expanding coffee economy offered, establishing themselves mainly in the sectors of clothing, linen and fabrics, cattle and cereals. Taking as main source a series of works in which the Syrian and Lebanese immigrants are portrayed in the interior, the article also indicates the main regions of west of São Paulo where the group mainly concentrated, and discusses trajectories which illustrate some of the possibilities of mobility, formation of leadership, the way religious practices have been transformed and the marked mobility - as doctors and politicians - achieved by strata of the first generation born in Brazil.

Keywords: Syrian and Lebanese. Western São Paulo. Social and economic mobility. Integration. Identity. Ethnic leadership. 


\section{Resumen}

Sirios y libaneses en el oeste de San Pablo

El artículo busca explorar los condicionantes y las características distintivas de la inserción socioeconómica de sirios y libaneses en el interior paulista entre la década del ochenta del siglo XIX y la del cincuenta del siglo XX. Del inicio difícil como vendedores ambulantes, portadores de una cultura distante, los sirios y libaneses lograron establecerse como comerciantes, aprovechando las oportunidades que sus redes - de parientes y de compatriotas- y que la economía cafetalera en expansión ofrecía se establecieron sobre todo en las ramas de ropa y tejidos, de mercería, y de ganado y cereales. Tomando como fuente principal una serie de obras en las que el inmigrante sirio y libanés es retratado en el interior, el artículo indica además las principales regiones del oeste paulista en las que el grupo se concentró, discute trayectorias que ilustran algunas de las posibilidades de movilidad, la formación de los líderes, el modo en que las prácticas religiosas se transformaron y la movilidad acentuada -como doctores y como políticos - conquistada por estratos de la primera generación nacida en Brasil.

Palabras clave: Sirios y libaneses. Oeste de San Pablo. Movilidad socioeconómica. Integración. Identidad. Liderazgo étnico.

Recebido para publicação em 19/05/2019

Aceito para publicação em 07/10/2019 